\title{
PENGARUH SENAM ASMA TERHADAP PENINGKATAN KEKUATAN OTOT PERNAFASAN (ARUS PUNCAK EKSPIRASI) PADA PENDERITA ASMA USIA PRODUKTIF DI WILAYAH KERJA PUSKESMAS KAMPUNG DALAM PONTIANAK TIMUR
}

\section{EFFECT OF ASTHMA GYMNASTICS ON MUSCLE STRENGTH ENHANCEMENT RESPIRATORY (PEAK EXPIRATION FLOW) IN ASTHMA PATIENTS PRODUCTIVE AGE IN THE WORK AREA KAMPUNG DALAM EAST PONTIANAK}

\author{
Delima Ritonga*, Ramadhaniyati*, Winarianti* \\ *Program Studi Keperawatan, Fakultas Kedokteran, Universitas Tanjungpura, \\ J1. Prof. Dr. H. Hadari Nawawi, Pontianak \\ Email: ritonga.delima@gmail.com
}

\begin{abstract}
ABSTRAK
Latar Belakang : Asma yang menyerang pada usia produktif cukup rentan terhadap aktivitas sehari-hari mereka. Pada penderita asma akan mengalami kelemahan otot-otot pernafasan dan penurunan arus puncak ekspirasi hal itu dapat memicu terjadinya dyspnea dan pembatasan aktivitas. Senam asma merupakan suatu jenis terapi latihan yang dilakukan secara berkelompok yang melibatkan aktivitas gerakan tubuh dan merupakan kegiatan yang membantu proses rehabilitas pernafasan, meningkatkan kemampuan otot-otot pernafasan, mencegah dan mengurangi kelainan bentuk dan sikap tubuh, mengendalikan dan meningkatkan kapasitas pernafasan dan meningkatkan percaya diri pasien penderita asma.

Tujuan : Mengidentifikasi Pengaruh Senam Asma terhadap Peningkatan Kekuatan Otot Pernafasan (Arus Puncak Ekspirasi) pada Penderita Asma Usia Produktif di Wilayah Kerja Puskesmas Kampung Dalam Pontianak Timur.

Metode : Penelitian Kuantitatif menggunakan pendekatan pre eksperiment dalam kategori satu kelompok (one group pretest- posttest design) pada 16 usia produktif tanpa kelompok kontrol yang mengalami asma melalui skrinning lembar observasi.. Beberapa instrumen APE yang digunakan dalam penelitian ini yaitu dengan melihat skor arus puncak ekspirasi pada penderita asma.

Hasil : Setelah diberikan senam asma pada penderita asma usia produktif menunjukan adanya peningkatan kekuatan otot pernafasan (arus puncak ekspirasi) yang ditunjukan oleh uji $t$ berpasangan yang memberikan nilai signifikan $\mathrm{p}<0,010$, dengan perubahan mean dari 506,81 \pm 91,326 menjadi 510,38 \pm 91,302

Kesimpulan : Adanya pengaruh senam asma terhadap peningkatan kekuatan otot pernafasan (arus puncak ekspirasi) pada penderita asma usia produktif di Wilayah Kerja Puskesmas Kampung Dalam Pontianak Timur. Sehingga senam asma sebaiknya menjadi program intervensi keperawatan pada manajemen asma untuk dapat meningkatkan kekuatan otot pernafasan dan fungsi paru pasien asma.
\end{abstract}

Kata Kunci : Asma, Arus Puncak Ekspirasi, Senam Asma

Referensi : (2003-2018) 


\begin{abstract}
Background : Asthma that attacks at productive age is quite susceptible to their daily activities. In people with asthma will experience weakness in respiratory muscles and a decrease in peak expiratory flow it can trigger dyspnea and limitation of activity. Asthma exercise is a type of exercise therapy that is carried out in groups that involve body movement activities and is an activity that helps the respiratory rehabilitation process, improves the ability of respiratory muscles, prevents and reduces deformities and body attitudes, controls and increases respiratory capacity and increases confidence patients with asthma.

Objective : To identify the effect of asthma gymnastics on increasing the strength of respiratory muscles (peak flow of aspiration) in patients with asthma productive age in the working area of Kampung Dalam East Pontianak.

Methods : Quantitative research using a pre-experiment approach in one group category (one group pretest-posttest design) in 16 productive ages without a control group experiencing asthma through screening observation sheets. Some APE instruments used in this study were by looking at the peak current score expiration in asthmatics.

Results : After being given asthma gymnastics in asthmatics the productive age showed an increase in respiratory muscle strength (peak expiratory flow) shown by paired t test which gave a significant value of $\mathrm{p}<0.010$, with a mean change from $506.81 \pm 91.3326$ to $510.38 \pm 91,302$

Conclusion : There is an effect of asthma gymnastics on increasing respiratory muscle strength (peak expiratory flow) in asthma sufferers of productive age in the Working Area of Kampung Dalam East Pontianak. So that asthma exercises should be a program of nursing intervention in asthma management to be able to increase respiratory muscle strength and pulmonary function of asthma patients.
\end{abstract}

\title{
Keywords : Asthma, Peak Expiration Flow, Asthma Gymnastics \\ References : (2003-2018)
}

\section{Pendahuluan}

Berbagai penyakit paru pada saat ini bermunculan dengan tingkat yang berbahaya dan sangat tinggi bahkan dapat menyebabkan kematian. Satu diantara penyakit paru yang saat ini banyak di derita oleh berbagai kalangan umur yaitu asma. Asma merupakan penyakit gangguan inflamasi kronis saluran pernapasan yang menyebabkan penyumbatan saluran napas yang episodik dan reversibel, di tandai dengan mengi, kesulitan bernafas, dada yang sesak, dan batuk. Inflamasi ini terjadi akibat peningkatan responsive saluran pernapasan terhadap berbagai stimulus (Holt, 2016). Penyakit asma yang merupakan masalah kesehatan dunia bukan hanya di negara maju bahkan terdapat di negara berkembang. Berdasarkan hasil catatan laporan dari Global Initiatif For Asthma (GINA) menyatakan bahwa jumlah pederita Asma di seluruh Dunia adalah 300 juta jiwa, 
dengan jumlah kematian yang signifikan meningkat hingga 180.000 jiwa per tahun. Adapun hasil data dari Report Word Health Organitation (WHO) tahun 2011 menunjukkan 300 juta jiwa di dunia terdiagnosa asma dan diperkirakan akan mengalami peningkatan sebesar 400 juta jiwa di tahun 2025, serta kematian asma yang mencapai 250.000 jiwa pertahun. Hasil data dari Riset Kesehatan Dasar Nasional tahun 2013, prevalensi asma di Kalimantan Barat sebesar 3,2\% dari seluruh kejadian nasional, dengan kejadian tertinggi pada perempuan $4,6 \%$ dan terjadi pada rentang umur 25-34 tahun sebagai usia kejadian tertinggi diikuti oleh rentang umur 35-44 tahun dan 15-24 tahun hal ini dapat dikatakan bahwa rentang umur yang demikian dapat dikatakan sebagai usia produktif dimana seseorang banyak melakukan aktivitas seperti bekerja atau kegiatan lainnya yang dapat menjadi pemicunya asma.

Gejala pada asma dapat membatasi manusia untuk berperilaku hidup normal dengan menyesuaikan kondisinya di lingkungan rumah tangga, masyarakat, dan lingkungan kerja sehingga orang dengan asma harus mengubah gaya hidupnya sesuai kondisi yang tidak akan menimbulkan serangan asma (Muttaqin,
2008). Gaya hidup sebagai bagian dari kehidupan manusia, secara langsung maupun tidak langsung dalam mempengaruhi berbagai aspek dalam kehidupan manusia. Satu diantara aspek yang dipengaruhi oleh gaya hidup tersebut yaitu kesehatan. Berbagai upaya manusia dalam meningkatkan upaya kesehatan jasmani maupun kesehatan fisik seperti latihan dan olahraga. Pasien asma dapat diwujudkan dengan penatalaksanaan asma yang tepat, dengan merubah tingkat keluhan yang minimal tetapi memiliki aktivitas yang maksimal, mencegah kekambuhan penyakit, hingga mencegah angka kematian (Sahat, Irawaty \& Hastono, 2011).

Asma ditegakkan berdasarkan anamnesis yang baik, pemeriksaan fisik, dan pengukuran faal paru. Pengukuran faal paru lebih objektif untuk menilai derajat obstruksi saluran napas dengan cara pengukuran Arus Puncak Respirasi (APE) menggunakan peak flow meter sedangkan Volume Ekspirasi Paksa dalam satu detik pertama (VEP1) dan Kapasitas Vital Paksa (KVP) diukur dengan spirometri (Sudrajat \& Nisa, 2016). Pada penderita asma akan mengalami kelemahan otot-otot pernafasan yang hal ini dapat memicu terjadinya dyspnea dan pembatasan 
aktivitas. Maka hal tersebut perlunya upaya pengobatan yang diberikan secara farmakologi dengan obat yang bersifat pengontrol maupun pelega pada asma. Namun, pengobatan ini tidak hanya ditunjang oleh obat-obatan yang dikonsumsi tetapi perlunya aktivitas fisik berupa olahraga maupun edukasi pada pecegahan dalam serangan asma. Olahraga seperti senam pada dasarnya membentuk dan mengembangkan pribadi secara harmonis yang dapat diartikan sebagai setiap bentuk latihan fisik yang disusun secara sistematis dengan melibatkan gerakan-gerakan yang terpilih dan terencana untuk mencapai tujuan tertentu. Senam pada asma dengan adanya gerakangerakan yang terstruktur dalam bentuk upaya tersebut yaitu dengan melakukan senam asma dengan memperkuat otot-otot pernafasan (Azhar \& Berawi, 2015).

Senam asma dengan adanya gerakan tubuh terutama lengan dan tungkai dianggap meningkatkan ventilasi paru dengan merangsang propioseptor sendi dan otot, yang kemudian menjalarkan eksitasi impuls ke pusat pernapasan (Sahat, Irawaty, \& Hastono, 2011). Senam asma yang dilakukan untuk pemenuhan kekuatan otot pada fungsi paru ini dengan tahapan awal yaitu menghitung nadi lalu mulai dengan gerakan pemanasan dan peregangan (10 menit) latihan inti A dan B (30 menit), lalu aerobik I (5 menit) serta pendinginan (5 menit) kemudian menghitung nadi kembali. Dalam tahapan gerakan-gerakan ini dimana pada tahap pemanasan dan peregangan yang dilakukan dalam waktu yang ditentukan agar otot-otot tidak langsung digunakan secara berlebihan yang akan menyebabkan kerusakan otot (Azhar \& Berawi, 2015).

Hasil wawancara dan pengambilan data awal yang peneliti lakukan pada Januari 2018, pada saat petugas kesehatan puskesmas melakukan pelayanan kesehatan dengan mewawancarai pada salah satu petugas didapatkan bahwa di Puskesmas Kampung Dalam hanya pernah melakukan senam jantung selama satu kali seminggu namun tidak pernah melakukan senam khusus asma dan pada penderita asma, data yang didapatkan dari tahun 2015-2017 di Puskesmas Kampung Dalam terdapat 417 jiwa penderita asma dengan menggunakan rentang umur yang dikategorikan anak-anak, remaja, dewasa dan lansia

Angka kejadian pada asma rata-rata pada rentang usia 20-59 tahun dimana hal ini menunjukan bahwa bukan hanya pada anak-anak maupun lansia saja yang dapat 
terkena asma namun meningkatnya penderita asma di usia produktif dengan adanya upaya pencegahan kekambuhan serangan asma oleh karena itu peneliti merasa perlu untuk melakukan intervensi "Pengaruh Senam Asma terhadap Peningkatan Kekuatan Otot Pernapasan (Arus Puncak Ekspirasi) pada Penderita Asma Usia Produktif di Wilayah Kerja Puskesmas Kampung Dalam Pontianak Timur".

\section{Metode}

Penelitian ini merupakan penelitian kuantitatif, dengan desain penelitian preeksperiment. Penelitian yang digunakan adalah dengan pendekatan one group pre test and post test without control yaitu suatu desain dimana peneliti hanya melakukan intervensi pada satu kelompok tanpa ada kelompok pembanding dan tidak dilakukan randomisasi untuk memasukan subjek ke dalam kelompok tersebut (Dharma,2015).

Penelitian ini dilaksanakan di Wilayah Kerja Puskesmas Kampung Dalam Pontianak Timur. Teknik yang digunakan adalah total samplimg. Jumlah sampel yang digunakan sebanyak 16 orang penderita asma yang diberikan senam asma.
Teknik analisa data menggunakan analisa univariat dan bivariat. Analisa univariat digunakan untuk mengetahui distribusi frekuensi masing-masing variabel yaitu peningkatan kekuatan otot pernafasan (arus puncak ekspirasi) pada penderita asma sebelum dan sesudah diberikan senam asma. Analisa bivariat dilakukan dengan cara uji t berpasanagn dengan tingkat kepercyaan 95\% untuk melihat perbedaan-perbedaan efektifitas intervensi senam asma terhadap peningkatan kekuatan otot pernafasan (arus puncak ekspirasi) pada penderita asma di Wilayah Kerja Puskesmas Kampung Dalam Pontianak Timur.

\section{Hasil}

\section{Analisa Univariat}

Tabel 1. Distribusi karakteristik berdasarkan Usia dan Jenis Kelamin

\begin{tabular}{llc}
\hline Usia & $(\boldsymbol{f})$ & $(\mathbf{\%})$ \\
\hline $15-49$ & 14 & 87,5 \\
$50-64$ & 2 & 12,5 \\
Total & $\mathbf{1 6}$ & $\mathbf{1 0 0}$ \\
\hline Jenis Kelamin & & \\
Laki-laki & 3 & 18,8 \\
Perempuan & 13 & 81,2 \\
Total & $\mathbf{1 6}$ & $\mathbf{1 0 0}$ \\
\hline
\end{tabular}

Berdasarkan tabel 1 didapatkan responden terbanyak adalah usia sangat produktif 15-49 berjumlah 14 orang 
(87,5\%) dan paling sedikit adalah usia produktif 50-64 berjumlah 2 orang $(12,5 \%)$. Jenis kelamin yang didapatkan terbanyak pada perempuan berjumlah 13 orang $(81,2 \%)$.

\section{Tabel 2. Distribusi karakteristik} berdasarkan Berat Badan, Pekerjaan dan Riwayat Penyakit Keluarga

\begin{tabular}{lcc}
\hline Berat Badan & $(\boldsymbol{f})$ & $\mathbf{( \% )}$ \\
\hline 41 & 1 & 6,2 \\
48 & 1 & 6,2 \\
55 & 2 & 12,5 \\
58 & 4 & 25,0 \\
60 & 6 & 37,5 \\
66 & 1 & 6,2 \\
$\quad 68$ & 1 & 6,2 \\
\multicolumn{1}{c}{ Total } & $\mathbf{1 6}$ & $\mathbf{1 0 0}$ \\
\hline Pekerjaan & & \\
Rumah tangga & 6 & 37,5 \\
OB & 1 & 6,2 \\
Wiraswasta & 7 & 43,8 \\
Swasta & 2 & 12,5 \\
Total & $\mathbf{1 6}$ & $\mathbf{1 0 0}$ \\
\hline Riwayat Penyakit & & \\
Keluarga & & \\
Ada & 14 & 87,5 \\
Tidak Ada & 2 & 12,5 \\
Total & $\mathbf{1 6}$ & $\mathbf{1 0 0}$ \\
\hline
\end{tabular}

Berdasarkan tabel 2 didapatkan responden yang terbanyak dengan berat badan $60 \mathrm{~kg}$ berjumlah 6 orang $(37,5 \%)$. Pekerjaan yang terbanyak pada Wiraswasta berjumlah 7 orang $(43,8 \%)$. Responden yang memiliki riwayat penyakit keluarga sebanyak 14 orang $(87,5 \%)$.
Tabel 3. Distribusi karakteristik berdasarkan kekuatan otot (APE) sebelum dan sesudah intervensi senam asma

\section{Skor Kekuatan}

Otot (APE)

$(f)$

(\%)

Skor Kekuatan

Otot (APE) sebelum

Kuning:250-400 5

31,2

Hijau : 450-800 11

68,8

Skor Kekuatan

Otot (APE) sesudah

Kuning : 250-400 $4 \quad 25,0$

Hijau : 450-800 $\quad 12 \quad 75,0$

$\begin{array}{lll}\text { Total } & 16 & 100\end{array}$

Berdasarkan tabel 3 didapatkan hasil skor kekuatan otot (APE) dalam penelitian ini dapat diketahui skor dalam zona kuning pada alat ukur peak flow meter sebelum diberikan intervensi senam asma sebanyak 5 orang $(31,2)$ dan pada zona hijau sebanyak 11 orang $(68,8)$, sesudah diberikan intervensi senam asma pada zona kuning sebanyak 4 orang $(25,0)$ dan zona hijau sebanyak 12 orang $(75,0)$. 


\section{Analisa Bivariat}

Tabel 4. Hasil skor Kekuatan Otot (APE) sebelum dan sesudah intervensi senam asma

\begin{tabular}{ccccc}
\hline Variabel & $\boldsymbol{f}$ & Mean & SD & P Value \\
\hline $\begin{array}{c}\text { Skor APE } \\
\text { sebelum }\end{array}$ & 16 & 506,81 & 91,326 & \\
$\begin{array}{c}\text { Skor APE } \\
\text { sesudah }\end{array}$ & 16 & 510,38 & 91,302 & 0,010 \\
\hline
\end{tabular}

Berdasarkan hasil analisis pada tabel 4 dapat dilihat diatas dari 16 responden, dikatakan ada pengaruh intervensi senam asma jika $<0,05$ dan didapatkan hasil mean skor kekuatan otot (APE) sebelum dilakukan intervensi senam asma di Wilayah Kerja Puskesmas Kampung Dalam Pontianak Timur yaitu 506,81 dengan standar deviasi 91,326. Dan mean skor kekuatan otot (APE) sesudah diberikan Intervensi senam asma yaitu 510,38 dengan standar deviasi 91,302.

\section{Pembahasan}

Pada penelitian ini bertujuan untuk mengetahui pengaruh senam asma terhadap peningkatan kekuatan otot pernafasan (APE). Pada karakteristik penderita asma berdasarkan usia didapatkan bahwa Pontianak responden yang terbanyak dengan rentang usia 15-49 tahun dengan jumlah 14 responden (87,5\%). Badan Pusat Statistik (2017) membedakan kelompok umur usia produktif menjadi 2 kategori yaitu usia sangat produktif (15-49), dan usia produktif (50-64), maka dalam penelitian ini respoden terbanyak pada usia sangat produktif. Hal ini sejalan dengan penelitian Prastyanto (2016) didapatkan hasil tertinggi pada usia rentang 25-34 tahun, kemudian di susul usia 15-24 tahun dan usia 35-44 tahun yang tergolong pada usia sangat produktif. Faal paru pada anak bertambah atau meningkat volumenya mencapai keadaan maksimal pada umur 19-21 tahun. Kekuatan otot pernafasan dan fungsi paru akan menurun sesuai pertambahan usia, hal ini disebabkan karena terjadi penurunan elastisitas dinding dada. Selama proses penuaan terjadi penurunan elastisitas alveoli, penebalan kelenjar bronkhial, penurunan kapasitas paru dan peningkatan jumlah ruang rugi, perubahan ini menyebabkan penurunan kapasitas difusi oksigen (Guyton \& Hall, 2014 dalam Antoro, 2015).

Pada karakteristik penderita asma berdasarkan jenis kelamin didapatkan bahwa jenis kelamin perempuan lebih banyak dengan jumlah 13 responden 
(81,2\%) dibandingkan laki-laki dengan jumlah 3 responden (18,8\%). Adapun hasil penelitian WHO (2016) menyatakan bahwa penyakit asma terbanyak diderita oleh jenis kelamin perempuan sebesar $(9,0 \%)$, dibandingkan dengan jenis kelamin laki-laki sebesar (6,3\%). Sejalan dengan hasil penelitian Antoro (2015) didapatkan bahwa responden perempuan sebanyak 23 orang persentase $(60,5 \%)$, dengan demikian perempuan memiliki kecenderungan lebih besar untuk memiliki asma dibandingkan laki-laki. Hal ini dikarenakan secara teori Guyton \& Hall (2011) dalam Antoro (2015) dikatakan bahwa fungsi paru laki-laki lebih tinggi 20\%-25\% dibandingkan perempuan, karena ukuran anotomi paru laki-laki lebih besar dibandingkan perempuan, selain itu aktivitas laki-laki lebih tinggi dibandingkan perempuan sehingga recoil dan complience paru sudah terlatih.

Pada karakteristik berdasarkan berat badan didapatkan bahwa responden yang memiliki berat badan $60 \mathrm{~kg}$ sebanyak 6 responden $(37,5)$. hal ini sejalan dengan hasil penelitian Sahat (2011), didapatkan hasil dengan berat badan rata-rata 59,72 $\mathrm{kg}$, hal ini berpengaruh pada kekuatan otot pernafasan dan fungsi paru dimana seseorang yang memiliki berat badan besar maka fungsi ventilasi parunya lebih kecil dan kemampuan dada untuk mengembang berbeda pada setiap berat badan yang berbeda.

Pada karakteristik berdasarkan pekerjan didapatkan bahwa responden yang terbanyak bekerja sebagai wiraswasta berjumlah 7 responden $(43,8 \%)$. Dari responden yang diteliti kebanyakan pekerjaan responden di wilayah tempat penelitian adalah sebagai pedagang dan kebanyakan responden berdagang hanya disekitar lingkungan rumah. Hal ini tidak sejalan dengan penelitian Antoro (2015) mengatakan bahwa pekerjaan merupakan faktor yang dapat memicu terjadinya serangan asma seperti lingkungan tempat kerja yang berhubungan dengan bahanbahan pembersih seperti cleaning, yang membuat orang harus berhubungan dengan bahan kimia, seperti pertanian, penataan rambut, percetakan dan sebagai pedagang di lingkungan pasar dimana hal ini yang dikarenkan aktivitas yang padat dipasar dapat membuat pasien stres sehingga dapat menyebabkan kekambuhan penyakit asma. Hal ini juga didukung oleh teori Jeyaratnam (2009), mengatakan bahwa terdapat banyak agens penyebab asma akibat kerja yaang paling umum 
seperti lingkungan kerja di industri yang menggunakan bahan kimiawi yang sangat reaktif, misalnya dalam pembuatan kasur dan bantal busa, bahan isolasi, cat, dan perekat. Agens penyebab umum lain termasuk debu penggilingan padi, debu kayu, uap solder dan las.

Pada karakteristik berdasarkan riwayat penyakit keluarga didapatkan bahwa jumlah responden terbanyak memiliki riwayat penyakit keluarga sebanyak 14 orang persentase $(87,5 \%)$. Hal ini sejalan dengan penelitian Bebasari \& Azrin (2016) didapatkan hasil bahwa responden terbanyak memiliki riwayat penyakit keluarga sebanyak 19 orang persentase (61,3\%), sebagian besar responden memiliki riwayat asma di keluarga. Hal ini juga di dukung pada teori oleh Muttaqin (2008), mengatakan bahwa pada klien dengan serangan asma perlu dikaji tentang riwayat penyakit asma atau penyakit alergi yang lain pada anggota keluarganya karena hipersensitivitas pada penyakit asma ini lebih ditentukan oleh faktor genetik dan lingkungan.

Berdasarkan hasil uji $\mathrm{T}$ Berpasangan nilai sig atau $p$ value $<0,010$ yang berarti Ho ditolak dan Ha diterima, disimpulkan bahwa ada pengaruh senam asma terhadap peningkatan kekuatan otot pernafasan
(APE) pada penderita asma usia produktif di Wilayah Kerja Puskesmas Kampung Dalam Pontianak Timur.

Pada penelitian ini setelah diberikan senam asma dengan durasi 55 menit yang diberikan selama 4 minggu dan diberikan senam 3 hari dalam seminggu, dimana intervensi yang diberikan dengan tahap pemanasan, peregangan inti $\mathrm{A}$ dan $\mathrm{B}$, Aerobik I serta pendinginan. Berdasarkan hasil penelitian Sudrajat \& Nisa (2016), didapatkan hasil dimana satu minggu pasien melakukan senam asma tiga kali dapat meningkatkan fungsi paru 11,9\%. Secara klinis peningkatan tersebut cukup baik, banyak responden yang rata-rata dari total semua sampel nilai APEnya sebelum diberikan intervensi 68,32\% dan setelah diberikan intervensi menjadi 80,22\%. Hal ini sejalan dengan penelitian oleh Antoro (2015), yang mengikuti senam asma dengan responden derajat ringan dan sedang, senam yang diberikan 1 kali seminggu yang dilakukan selama 60 menit selama 6 minggu didapatkan hasil yang diberikan sebelum senam asma 329,47 $\mathrm{ml} / \mathrm{mnt}$ menjadi $342,11 \mathrm{ml} /$ menit terdapat adanya perbedaan antara sebelum dan sesudah 12,63 $\mathrm{ml} / \mathrm{mnt}$ dengan standar deviasi 24,45 $\mathrm{ml} / \mathrm{mnt}$, oleh sebab itu semakin lama diberikan senam asma maka 
semakin besar adanya pengaruh terhadap peningkatan fungsi paru pada penderita asma. Perbedaan hasil senam asma pada penelitian sebelumnya dengan penelitian ini di ketahui bahwa senam yang dilakukan satu kali dalam seminggu selama enam bulan lebih menunjukan hasil dengan rata-rata yang lebih tinggi dibandingkan senam asma yang diberikan tiga kali dalam seminggu selama satu bulan pada penelitian ini.

Teori ini didukung oleh penelitian Sudrajat \& Nisa (2016) mengatakan bahwa latihan fisik seperti senam asma menyebabkan perangsangan pusat otak yang lebih tinggi pada pusat vasomotor di batang otak yang menyebabkan terjadinya peningkatan tekanan arteri dan ventilasi paru, seperti pada senam asma ini dengan gerakan tubuh terutama lengan dan tungkai dianggap meningkatkan ventilasi paru dengan merangsang propioseptor sendi dan otot, yang kemudian menjalarkan impuls eksitasi ke pusat pernafasan. Hipoksia yang terjadi didalam otot selama senam, menghasilkan sinyal saraf aferen ke pusat pernafasan untuk merangsang pernafasan. Hal ini juga karena otot-otot yang bekerja akan membentuk karbondioksida $\left(\mathrm{CO}_{2}\right)$ dan oksigen $\left(\mathrm{O}_{2}\right)$ berubah secara nyata antar siklus inspirasi dan siklus ekspirasi pada pernafasan.

Pasien asma harus terus melakukan senam asma secara rutin untuk mendapatkan kekuatan otot pernafasan secara maksimal dan mengevaluasinya secara berkala, olahraga dengan melatih otot-otot pernafasan seperti senam asma secara rutin akan meningkatkan kerja jantung, sehingga peredaran darah ke seluruh tubuh bertambah lancar, khususnya kepada otot-otot tubuh termasuk otot pernafasan. Aliran darah yang lancar akan membawa nutrisi dan oksigen yang lebih banyak ke otot-otot pernafasan

\section{Kesimpulan}

Hasil penelitian yang telah dilaksanakan di Wilayah Kerja Puskesmas Kampung Dalam Pontianak Timur pada tanggal 16 Juli 2018 sampai tanggal 16 Agustus 2018 peneliti mulai melakukan penelitian pada kelompok intervensi maka dapat disimpulkan bahwa :

1. Karakteristik responden dalam penelitian ini mayoritas berada dalam kelompok umur 15-49 tahun. Jenis kelamin didominasi oleh perempuan $(81,2 \%)$. Berat badan terbanyak $60 \mathrm{~kg}$ (37,5\%). Pekerjaan pada penelitian ini mayoritas sebagai wiraswasta (dagang) 
$(43,8 \%)$. Jumlah responden terbanyak dengan memiliki riwayat penyakit keluarga (87,5\%). Kekuatan otot (APE) yang diberikan sebelum dan sesudah senam asma rata-rata mengalami peningkatan di zona hijau.

2. Uji T Berpasangan menunjukan nilai $p$ value $<0,010$ yang berarti Ho ditolak Ha diterima, disimpulkan bahwa ada pengaruh senam asma terhadap peningkatan kekuatan otot pernafasan (arus puncak ekspirasi) pada penderita asma usia produktif di Wilayah Kerja Puskesmas Kampung Dalam Pontianak Timur.

\section{Saran}

Beberapa saran yang dapat disampaikan berdasarkan hasil penelitian ini antara lain untuk institusi pendidikan keperawatan, peneliti, lahan penelitian, dan penelitian selanjutnya adalah :

1. Bagi pendidikan keperawatan

Hasil penelitian ini dapat digunakan sebagai masukan data untuk melakukan upaya-upaya dalam peningkatan pemberian pengetahuan kepada seluruh mahasiswa dalam bidang kesehatan khususnya tentang penyakit asma pada usia produktif.
2. Bagi peneliti

Bagi peneliti dapat memberikan pengalaman dalam meneliti serta diharapkan dapat memanfaatkan hasil penelitian yang telah didapatkan dengan menerapkannya dalam bidang keperawatan terutama dalam hal pemberian intervensi non-farmakologi yang tepat untuk mengatasi penderita asma selain menggunakan tindakan farmakologi.

3. Bagi lahan penelitian

Hasil Penelitian ini dapat memberikan kontribusi bagi Dinas Kesehatan Kota Pontianak dan Puskesmas setempat yang bisa dipakai sebagai bahan pertimbangan untuk mengadakan program mengurangi kekambuhan asma melaui senam asma.

4. Bagi peneliti selanjutnya

Hasil dari penelitian ini dapat digunakan sebagai data dasar untuk melakukan penelitian lebih lanjut dan dapat melanjutkan temuan-temuan baru pada penelitian ini khususnya yang berkaitan dengan penyakit asma dengan variabel yang berbeda atau waktu pemberian yang berbeda dan melibatkan intervensi tambahan yang berhubungan dengan peningkatan kapasitas paru oleh penderita asma. 
Daftar Pustaka

Antoro, B. (2015). Pengaruh

Senam Asma Tersruktur Terhadap

Peningkatan Arus Puncak Ekspirasi (APE) pada Pasien Asma. Jurnal Kesehatan , VI

(1), 7172.

Azhar, A. H., \& Berawi, K. N. (2015). Hubungan Rutinitas Senam Asma Terhadap Faal Paru Pada Penderita Asma. Majority, IV (9), 2.

Bebasari, E., \& Azrin, M. (2016). Kolerasi Lama Senan Asma dengan Faal Paru Pada Pasien yang Mengikuti Senam Asma. JIK, X (1), 17-18.

Dharma, K. K. (2015). Metodologi Penelitian Keperawatan. Jakarta: Trans Info Media.

Global Initiative for Asthma (GINA). 2017. Global strategy for asthma management and prevention.

Holt, S. (2016). Cochrane Corner: Yoga for asthma. Advances in Integrative Medicine, III (1), 35

Jeyaratnam, J. (2009). Buku Ajar Praktik Keperawatan Kerja. Jakarta: EGC.

Muttaqin, A. (2008). Buku Ajar Asuhan Keperawatan Klien Dengan Gangguan Sistem Pernapasan. Jakarta: Selemba medika.
Prastyanto, Dandy. (2016).

Pengaruh Latihan Pernafasan Buteyko Terhadap Arus Puncak Ekspirasi

(APE) Pada Penderita Asma. Universitas Negeri Yogyakarta.

Riset kesehatan dasar 2013.

Jakarta: Balitbang Kesehatan

Kemenkes RI, 2013.

Sahat, C. S., Irawaty, D., \& Hastono, S. P. (2011). Peningkatan Kekuatan Otot Pernafasan dan Fungsi Paru Melalui Senam Asma Pada Pasien Asma. Jurnal Keperawatan Indonesia , XVI (2), 101-102.

Sudrajat, \& Nisa, K. (2016).

Efektifitas Senam Asma untuk Meningkatkan Fungsi Paru Penderita Asma. Majority, $V(4), 4$. 